\title{
Influences of flood and ebb tides on nutrient fluxes and chlorophyll on an intertidal flat
}

\author{
Kedong Yin ${ }^{1, *}$, Paul J. Harrison ${ }^{2}$ \\ 'Department of Biology, Hong Kong University of Science and Technology, Clear Water Bay, Kowloon, Hong Kong, SAR \\ ${ }^{2}$ Oceanography, Department of Earth and Ocean Sciences, University of British Columbia, Vancouver V6T 1Z4 Canada
}

\begin{abstract}
Intertidal estuarine sediment processes produce organics and nutrients and are influenced by river outflow and tidal cycles. Hence the sediments act as a source or sink of nutrients into or out of the water column. In most studies, a chamber incubation approach is used to study fluxes of nutrients into and out of the sediment; the chamber isolates the sediments from the hydrodynamics occurring in the overlying water column. Therefore, field data over an entire intertidal flat are lacking. Here, we present a unique case in which an intertidal flat is semi-enclosed, usually inundated for 12 to $14 \mathrm{~h}$ during a tidal cycle, and hence can be treated like an incubation chamber during this period of submergence. The intertidal flat on Sturgeon Bank, British Columbia, was directly exposed to domestic sewage effluents from the Iona Sewage Treatment Plant between 1967 and 1989. Since 1989, the sewage effluent has been diverted and discharged into deep water in the Strait of Georgia. The objective of the present study was to determine the effects of tidal cycles on the flux of nutrients from the sediment into the water column. We expanded the spatial scale of our study site by treating the semienclosed tidal flat as a large natural incubation chamber during the 12 to 14 h period of submergence. Water samples at 10 stations covering Sturgeon Bank were taken during late flood tides and middle ebb tides, 12 to $13 \mathrm{~h}$ later. Salinity, temperature, chl a, nutrients $\left(\mathrm{NH}_{4}, \mathrm{NO}_{3}\right.$ and $\left.\mathrm{PO}_{4}\right)$, suspended load, and particulate carbon (PC) and nitrogen (PN) at the surface were measured or analyzed. Based on nearly 2 yr observation between 1994 and 1995, we found that water coming onto Sturgeon Bank was a mixture of different origins since salinity was not correlated with temperature or any other variables except for particulate $\mathrm{C} / \mathrm{N}$. Chl a was higher during flood tides than during ebb tides, indicating a loss of chl a from the water column, likely due to feeding by benthic organisms. Ammonium concentrations were almost always higher during ebb tides than flood tides, indicating a release of $\mathrm{NH}_{4}$ from the sediment. Therefore, the intertidal flat of Sturgeon Bank appears to be a sink for chl a and a source of $\mathrm{NH}_{4}$ to the Strait of Georgia. Particulate $\mathrm{C} / \mathrm{N}$ ratios were always higher than 7 , indicating a predominantly terrestrial origin of particulate organics. Particulate $\mathrm{C} / \mathrm{N}$ ratios were also found to be higher during ebb tides than flood tides, indicating preferential utilization of PN when organic matter was deposited onto the sediment. Our study has shown that it is possible to treat an intertidal flat as an incubation chamber and follow fluxes of nutrients and particulates into and out of the water column during flood and ebb tides. With this approach, we concluded from $\mathrm{NH}_{4}$ concentrations and fluxes that the intertidal flat at Sturgeon Bank showed no signs of eutrophication due to previous sewage effluent contamination.
\end{abstract}

KEY WORDS: Pelagic-benthic coupling - Nutrient source - Chl a sink · Intertidal flat - Tidal cycle . Sturgeon Bank

\section{INTRODUCTION}

Processes in estuarine sediment regulate the flow of nutrients from terrestrial sources to the ocean and influence the overall productivity of estuarine ecosys-

\footnotetext{
-E-mail:kyin@ust.hk
}

tems (Nixon 1981). In general, $25 \%$ of the nitrogen used in primary productivity in the water column is supplied by nitrogen fluxes from the sediments (Fisher et al. 1982, Kemp \& Boynton 1984). On the other hand, between $1 / 4$ and $1 / 2$ of the allochthonous carbon inputs plus autochthonous primary productivity are oxidized by the sediments (Nixon \& Pilson 1983). Due to the increase in human pollution, estuarine sediments also 
represent a primary repository for anthropogenic chemicals entering the marine environment (Means et al. 1989, cf. Demuth et al. 1993).

The study sites were on Sturgeon Bank, which is an intertidal flat located west of Vancouver (see Fig. 1). Its landward margin is fringed by a $1 \mathrm{~km}$ wide brackish marsh, and the sedimentary flat is $5 \mathrm{~km}$ wide and extends into the Strait of Georgia. To the south, the Steveston Jetty separates Sturgeon Bank from the Main Arm (South Arm) of the Fraser River, and the Iona Jetty (6 km long) divides Sturgeon Bank into 2 flats of which the southern part is larger than the northern part. The Middle Arm of the Fraser River discharges directly onto the intertidal flat, while the river discharge or the riverine plume from the Main Arm invades the flat with tidal flows and through the jetty openings. Tidal cycles in the Strait of Georgia are mainly semi-diurnal (LeBlond 1983). Tidal ranges are between 2 and $5 \mathrm{~m}$ due to the change in height of the lower low water during spring and neap tides. During flood tides, seawater inundates the flat and dams the river flow of both the Main and Middle Arms of the Fraser River. During ebb tides, the river flow increases and the flat is exposed. The Fraser River discharge is minimal in winter, starts to increase in April, reaches a maximum in June and then gradually decreases until September. The flat consists mostly of sandy sediments (Luternauer \& Murray 1973).

Between 1962 and 1988, the Iona Sewage Treatment Plant on Iona Island discharged primary treated sewage (estimated $23000 \mathrm{~kg}$ suspended solids $\mathrm{d}^{-1}$ ) into a ditch along the south side of the Iona Jetty. The initial intention was to discharge sewage effluent during flood tides so that the effluent could retreat into the Strait of Georgia with ebb tides and be further diluted with seawater in the Strait. However, depending on wind conditions and the phases of the (spring vs neap) tidal cycle every 2 wk, the effluent frequently spilled onto the intertidal flat and solids settled onto the sediment. Part of the intertidal ecosystem was heavily contaminated during this period. Early studies have shown that heavy metals (especially $\mathrm{Hg}$ ) were very high near the outfall and decreased as one moved further away (McGreer 1979, Thomas \& Bendell-Young 1998). Diversity of benthic fauna was very low at sites near the outfall and increased with the distance from the outfall (Otte \& Levings 1975).

Beginning in 1989, the primary treated sewage was diverted directly into the deep water (approximately $100 \mathrm{~m}$ deep) in the Strait of Georgia, through 2 large pipes. This diversion has largely reduced direct effluent pollution of the intertidal flat and allowed the intertidal ecosystem to recover from earlier contamination. This diversion offered a unique opportunity to study the recovery process. This study was part of a larger project initiated in 1994 under the Fraser River Action Plan and involved multi-disciplinary studies on topics including heavy metals in sediments (Thomas \& Bendell-Young 1998), sediment nutrient dynamics (Yin et al. unpubl. data), benthic algal biomass (Yin et al. unpubl. manuscript), benthic primary productivity (Ross 1998), and dynamics of important invertebrates such as Macoma sp. and Corophium sp. (Arvai 1997) and shore bird feeding (Sewell 1996).

Most studies have focused on the processes in subtidal estuarine sediments that are constantly under water as opposed to processes in intertidal sediments (Nixon 1981). Estuarine intertidal flats are an important interface between terrestrial river discharge and marine waters and often form part of estuarine deltas. Estuarine intertidal sediments receive large amounts of sediment-bound nutrients and organic detritus from the river and act like a platform for processing these sediment-bound organics or nutrients that pass through it. Therefore, intertidal sediments may represent a source or sink of a nutrient into or out of the water column during tidal cycles. The processes involved in the uptake or release of nutrients from the sediment are complex and will depend on the location, depth within the water column and tidal phases (Wolaver \& Zicman 1983). Whether the sediment acts as a sink or source is also nutrient-specific and seasonally dependent (Watson et al. 1993).

In most studies, observations are obtained with the chamber incubation method which does not match the scale of intertidal flats. In this study, we treated a semienclosed intertidal flat like an incubation chamber and sampled the water column between flood and ebb tides over the entire flat for salinity, nutrients, particulate carbon (PC) and nitrogen (PN). The objectives of the present work were to: (1) examine whether the intertidal flat is a source or sink of nutrients for the Strait of Georgia, (2) to determine what regulates nutrients and chl in the exchange between the water and the flat, and (3) assess the effects of tidal cycles on nutrients and chl a on the flat and in the water column of the Strait of Georgia.

\section{MATERIALS AND METHODS}

The area of Sturgeon Bank between the north and south jetties (Fig. 1) forms an enclosed flat that opens to the tidal waters of the Strait of Georgia. This area of Sturgeon Bank serves as a natural incubator: water fills the area during a flood tide, incubates over 12 to $14 \mathrm{~h}$ and leaves during the following ebb tide. Our sampling strategy was based on this concept. Due to the semi-diurnal nature of the tides in this area, there is sometimes a higher low water (HLW) phase of the tidal 
cycle during the 12 to $14 \mathrm{~h}$. The HLW is usually about $3 \mathrm{~m}$ in the Tidal Water Table, and, at this water level, the flat is still inundated by tidal water. The less strong ebb and flood periods are excluded when we refer to flood and ebb tides in our results.

Stations, sampling time and sampling protocol. Ten sampling stations were selected (Fig. 1; W1 to W10). Five stations (W1 to W5) were constantly under water at the $10 \mathrm{~m}$ depth contour offshore. The other 5 near-shore stations ( $W 6$ to W10) were in the middle of the intertidal flat; they were covered by water during high tides and exposed to the air during low tides. The near-shore stations were $\sim 3 \mathrm{~m}$ at higher high water. The water was sampled. during the late stage of a flood tide and during the middle stage of the following ebb tide. Therefore, changes in water parameter values during this time period provided information on the interaction between the overlying water and sediment. The sampling frequency was bi-weekly in spring and summer, and monthly or longer in fall and winter. Sampling always took place during spring tides.

A water analyzer was used in situ to measure salinity and temperature. At each station, surface water was collected with a plastic bucket. All water samples were stored in $1 \mathrm{l}$ polyethylene bottles and transported to the laboratory in coolers for the analyses of chl $a$, $\mathrm{PC}$ and $\mathrm{PN}$ a few hours later. Subsamples for nutrients $\left(\mathrm{NO}_{3}, \mathrm{NH}_{4}\right.$ and $\left.\mathrm{PO}_{4}\right)$ were immediately filtered via a syringe and Swinex filter holder into acid-cleaned bottles through $25 \mathrm{~mm} \mathrm{GF/F}$ filters which were pre-combusted at $480^{\circ} \mathrm{C}$ for $4 \mathrm{~h}$. These nutrient samples were frozen within $4 \mathrm{~h}$ and kept for later analysis.

Analytical methods. Samples for chl a (200 to $300 \mathrm{ml}$ ) were filtered onto Whatman GF/F filters. Filters were placed into $10 \mathrm{ml}$ of $90 \%$ acetone and sonicated (in the dark) for 10 min in ice-cold water. After sonication, chl $a$ was extracted in the cold and dark for $24 \mathrm{~h}$ in $90 \%$ acetone, and analyzed by in vitro fluorometry (Parsons et al. 1984) using a Turner Designs ${ }^{\circledR}$ Model 10 fluorometer.

Samples for suspended loads were collected on precombusted $\mathrm{GF} / \mathrm{F}$ filters, dried for $24 \mathrm{~h}$ at $<60^{\circ} \mathrm{C}$ and weighed. The average weight of $10 \mathrm{GF} / \mathrm{F}$ filters was subtracted from each sediment-containing filter in order to obtain the amount of suspended load on a filter. Samples for PC and PN (usually $400 \mathrm{ml}$ ) were collected on combusted $\left(460^{\circ} \mathrm{C}\right.$ for $\left.4 \mathrm{~h}\right)$ Whatman $^{*} \mathrm{GF} / \mathrm{F}$ filters and stored frozen in a desiccator. The filters were dried for $24 \mathrm{~h}$ at $<60^{\circ} \mathrm{C}$ and analyzed with a Carlo

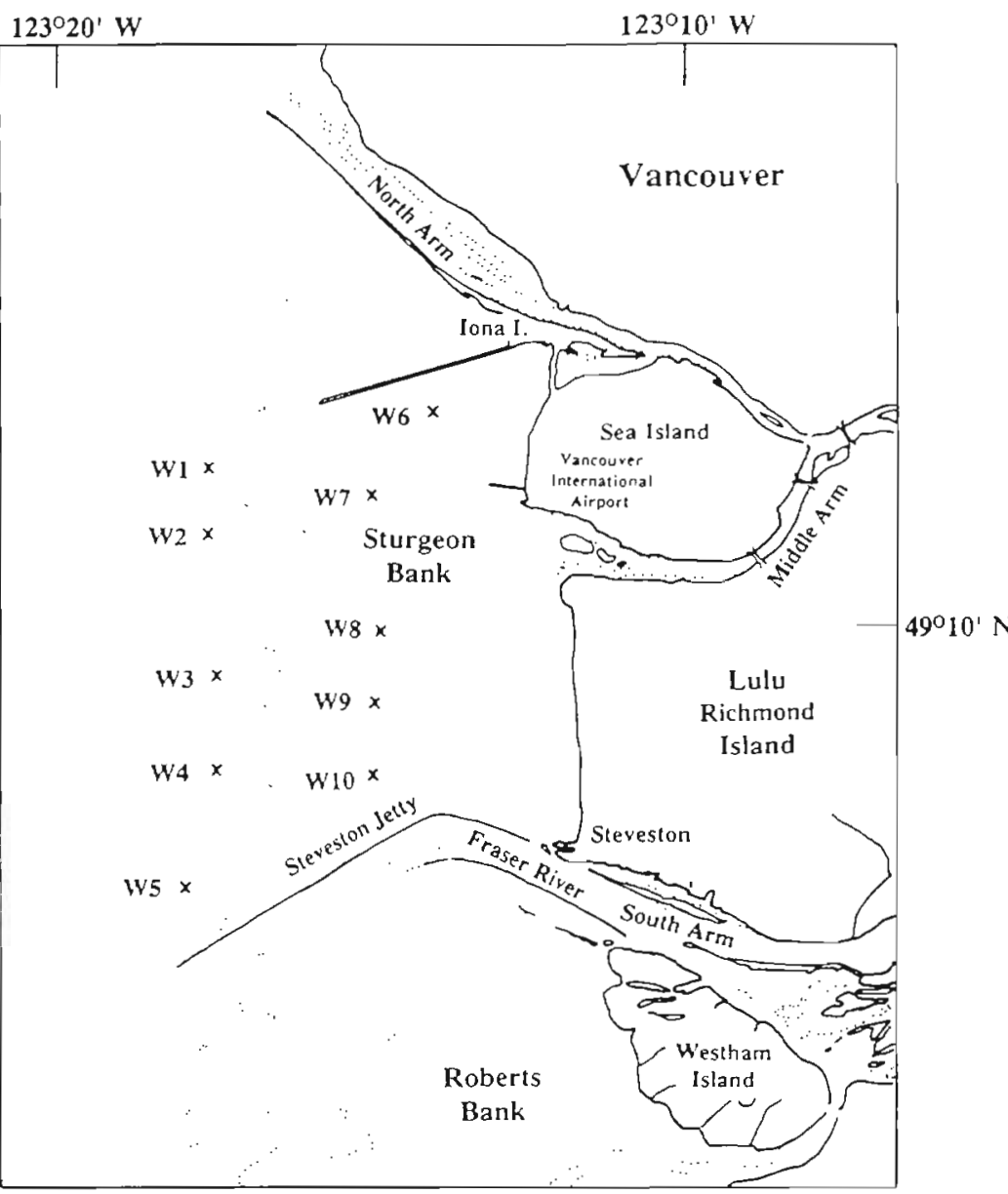

Fig. 1. Map of Sturgeon Bank and Roberts Bank. Dotted line on the right indicates the edge of the marsh and on the left the lowest (LLW) tidal line. The hovercraft positioning uses GPS which is accurate to within 25 or $50 \mathrm{~m}$ depending on weather

Erba Model NA 1500 NCS elemental analyzer, using the dry combustion method described by Sharp (1974).

All nutrients were determined using a Technicon AutoAnalyzer ${ }^{(11}$ II. No correction was made for salinity effects since salinity effects on nutrient analysis were tested and were found to be small (Collos et al. 1992). Nitrate (plus nitrite) and ammonium were determined following the procedures of Wood et al. (1967) and Slawyk \& Maclsaac (1972), respectively. Phosphate was analyzed according to Hager et al. (1968).

\section{RESULTS}

Salinity was lower during ebb tides than during flood tides (Fig. 2), indicating more freshwater outflow from the Fraser River during ebb tides. This was consistent with other studies where the freshwater outflow is dammed during flood tides and released during ebb tides (LeBlond 1983, Geyer \& Farmer 1989). Salinity of 


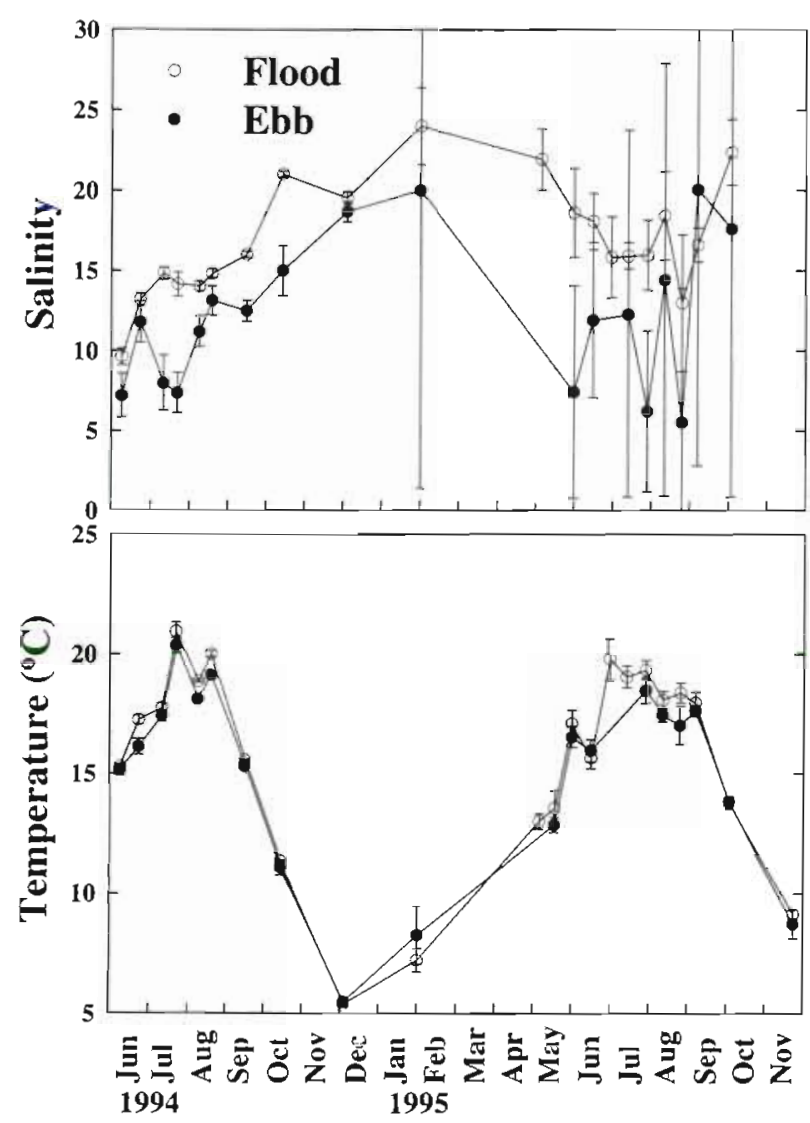

Fig. 2. Time series of salinity and temperature in the water column (average of the 10 stations) during tidal floods and ebbs for 1994 and 1995. Error bars $= \pm 1$ SE $(n=10)$

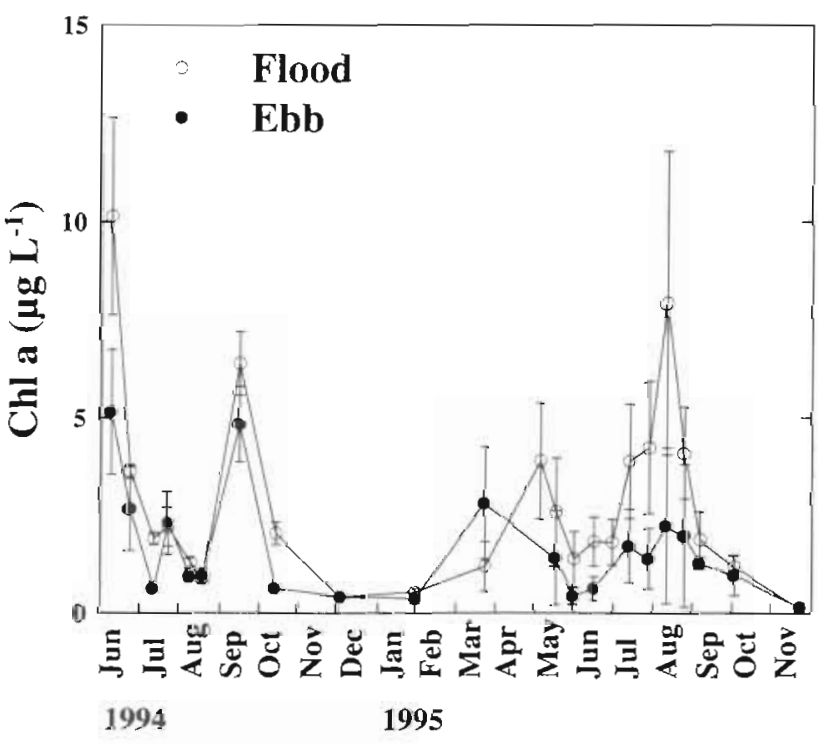

Fig. 3. Time series of chl $a$ in the water column (average of the 10 stations) during tidal floods and ebbs for 1994 and 1995. ETIOT bars $= \pm 1$ SE $(n=10)$

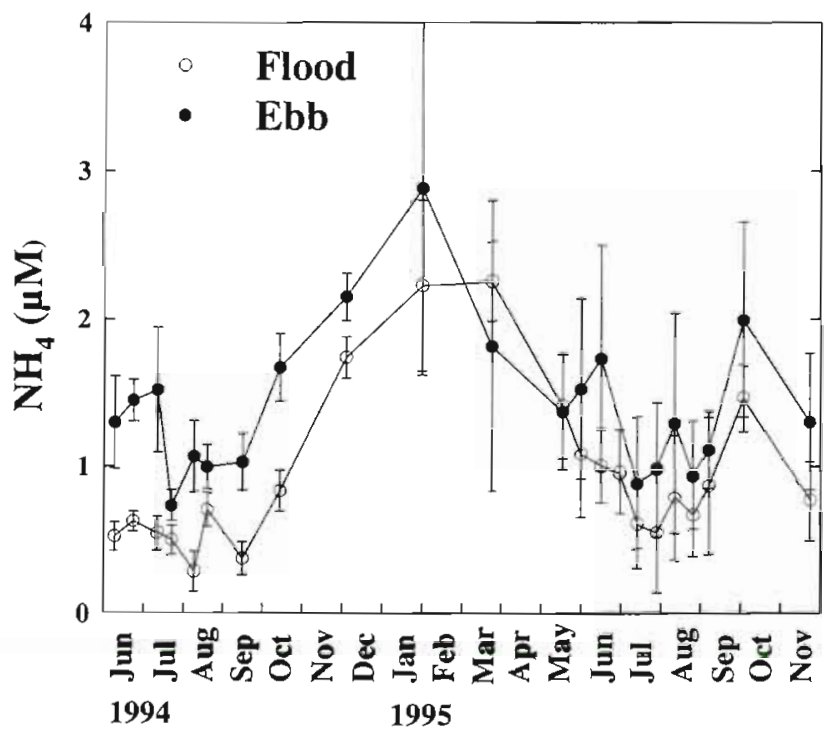

Fig. 4. Time series of $\mathrm{NH}_{4}$ in the water column (average of the 10 stations) during tidal floods and ebbs for 1994 and 1995. Error bars $= \pm 1 \mathrm{SE}(n=10)$

the surface water during flood and ebb tides was low (around 10) in June and July and high (near 20) in December and January (Fig. 2). This reflected the maximum freshwater outflow from the Fraser River in June and the minimum in winter. The temperature of the surface water showed obvious seasonality, being highest in July and August (around $20^{\circ} \mathrm{C}$ ) and decreasing to the lowest value in December $\left(5^{\circ} \mathrm{C}\right)$ (Fig. 2). However, variations in temperature among the 10 stations were small, and the differences were also small between flood and ebb tides, although temperature was usually higher during flood tides than during ebb tides.

Chl a during ebb tides was lower than during flood tides over most of the sampling period (Fig. 3). This indicated that the water column lost chl $a$, possibly to the sediment. The loss appeared to be higher when chl $a$ in the flood tide water was high (Fig. 3). There were temporal fluctuations in chl a over the 2 yr. The spring bloom is commonly observed during late March and early April in the Strait of Georgia (Parsons et al. 1969, Yin et al. 1996, 1997a). However, chl a in March (22 March) 1995 was low and increased in May (4 May) (Fig. 3). This indicated that the spring bloom was developing during the April period. There was a chl a peak of $10 \mathrm{~kg} \mathrm{l}^{-1}$ in June 1994 in the flood tide water, which was high for the Strait of Georgia. This peak did not occur in 1995. High chl a $\left(6 \mu \mathrm{g} \mathrm{l}^{-1}\right)$ observed in September 1994 occurred in August 1995 (Fig. 3).

Ammonium concentrations were high in winter and low in summer (Fig. 4), although $\mathrm{NH}_{4}$ was rarely depleted. $\mathrm{NH}_{4}$ concentrations were higher during ebb 
tides than during flood tides except for 2 occasions $(22$ to 23 March and 16 to 17 May 1995, Fig. 4). This indicated that $\mathrm{NH}_{4}$ was released into the water column.

Temporal variation of $\mathrm{NO}_{3}$ concentrations was strong, with low concentrations from June to September $(<3 \mu \mathrm{M}) 1994$ and dramatically higher concentrations during October 1994 to March 1995. When $\mathrm{NO}_{3}$ concentrations were low (Fig. 5), $\mathrm{NO}_{3}$ was higher during ebb tides than during flood tides, indicating a release of $\mathrm{NO}_{3}$ into the water column from the sediment. However, when $\mathrm{NO}_{3}$ was high (as in winter), $\mathrm{NO}_{3}$ was lower during ebb tides than during flood tides, indicating the loss of $\mathrm{NO}_{3}$ from the water column to the sediment. High $\mathrm{NO}_{3}$ in late March (22 March) 1995 was consistent with low chl a for the same day. This might be due to a continuation of the winter conditions since the spring bloom had not consumed $\mathrm{NO}_{3}$ (Yin et al. 1997a) or might be due to wind mixing, as was observed in the Strait of Georgia (Yin et al. 1997b).

The temporal fluctuations in $\mathrm{PO}_{4}$ concentrations were similar to $\mathrm{NO}_{3}$. However, $\mathrm{PO}_{4}$ concentrations were not consistently higher or lower between flood and ebb tides (Fig. 6). This is possibly due to the complicated adsorption or desorption of $\mathrm{PO}_{4}$ from sediments during the period of high freshwater influence. Previous observations indicated that when water samples were filtered (as was the case in this study), a considerable amount of sediment-bound $\mathrm{PO}_{4}$ was removed by filtering out the sediment particles (Harrison et al. unpubl.).

Suspended load showed little temporal variation during flood tides over 2 yr, but showed 2 peaks in the outgoing ebb water in July and August 1994 and June

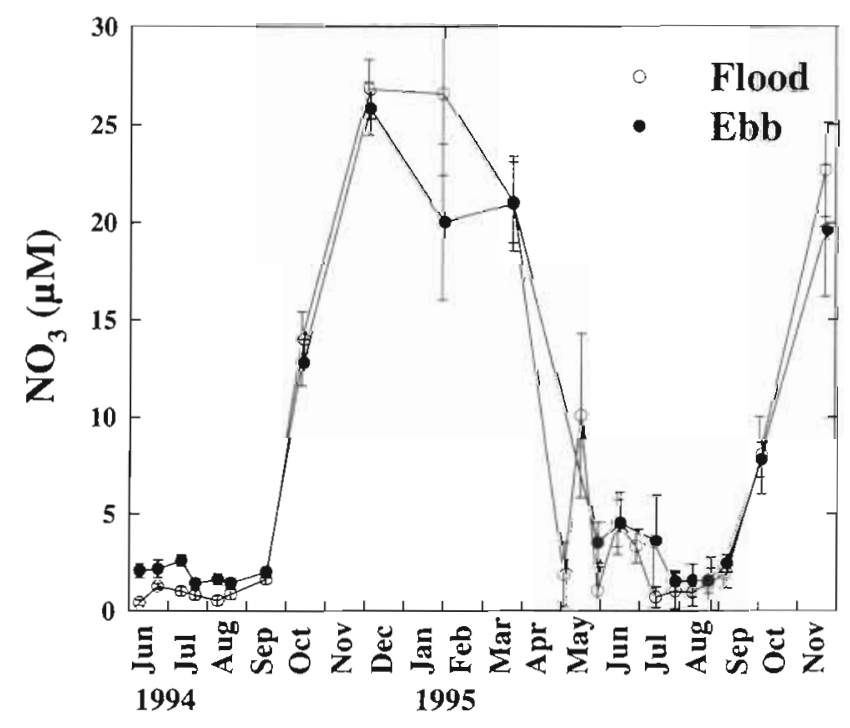

Fig. 5. Time series of $\mathrm{NO}_{3}$ in the water column (average of the 10 stations) during tidal floods and ebbs for 1994 and 1995. Error bars $= \pm 1 \operatorname{SE}(n=10)$

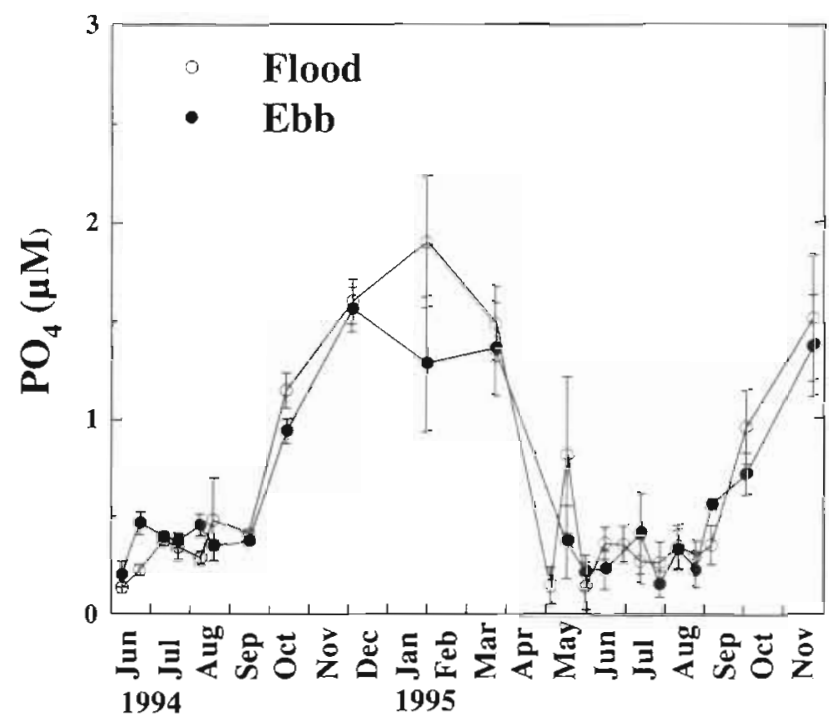

Fig. 6. Time series of $\mathrm{PO}_{4}$ in the water column (average of the 10 stations) during tidal floods and ebbs for 1994 and 1995. Error bars $= \pm 1 \mathrm{SE}(\mathrm{n}=10)$

1995 (Fig. 7A). Fluctuations in PC (Fig. 7B) and PN (Fig. 7C) were similar to suspended load. PC ranged from $30 \mu \mathrm{M}$ in winter to a peak of $120 \mu \mathrm{M}$ in August 1994, while PN was as low as $2 \mu \mathrm{M}$ in winter, but was higher in late spring and summer. PC/PN ratios were mostly higher than 6.7 (Fig. 7D).

\section{DISCUSSION}

\section{Water masses on Sturgeon Bank}

A freshwater influence was dominant over Sturgeon Bank based on the range of temporal fluctuations in salinity. However, water masses on Sturgeon Bank did not appear to have any particular spatial pattern. There were no large differences in salinity among stations for either year except for Stn W7 which is near the channel of the Fraser River Middle Arm and Stn W10 which might be influenced by freshwater passing through the openings in the Steveston Jetty (Fig. 8). The analysis of salinity-temperature diagrams also indicates different sources of water masses coming onto and leaving the tidal flat, since the correlation between salinity and temperature at 10 stations for flood or ebb tides was not significant for most tidal cycles (Fig. 9). Such a mosaic of water masses on Sturgeon Bank is not unexpected. Our previous studies have shown that the water masses near the Fraser River estuary are complex due to the presence of the riverine plume, estuarine plume and deep seawater (Yin et al. 1995a). The dynamics can be further complicated by tidal cycles and winds (Feeney 1995, Yin 


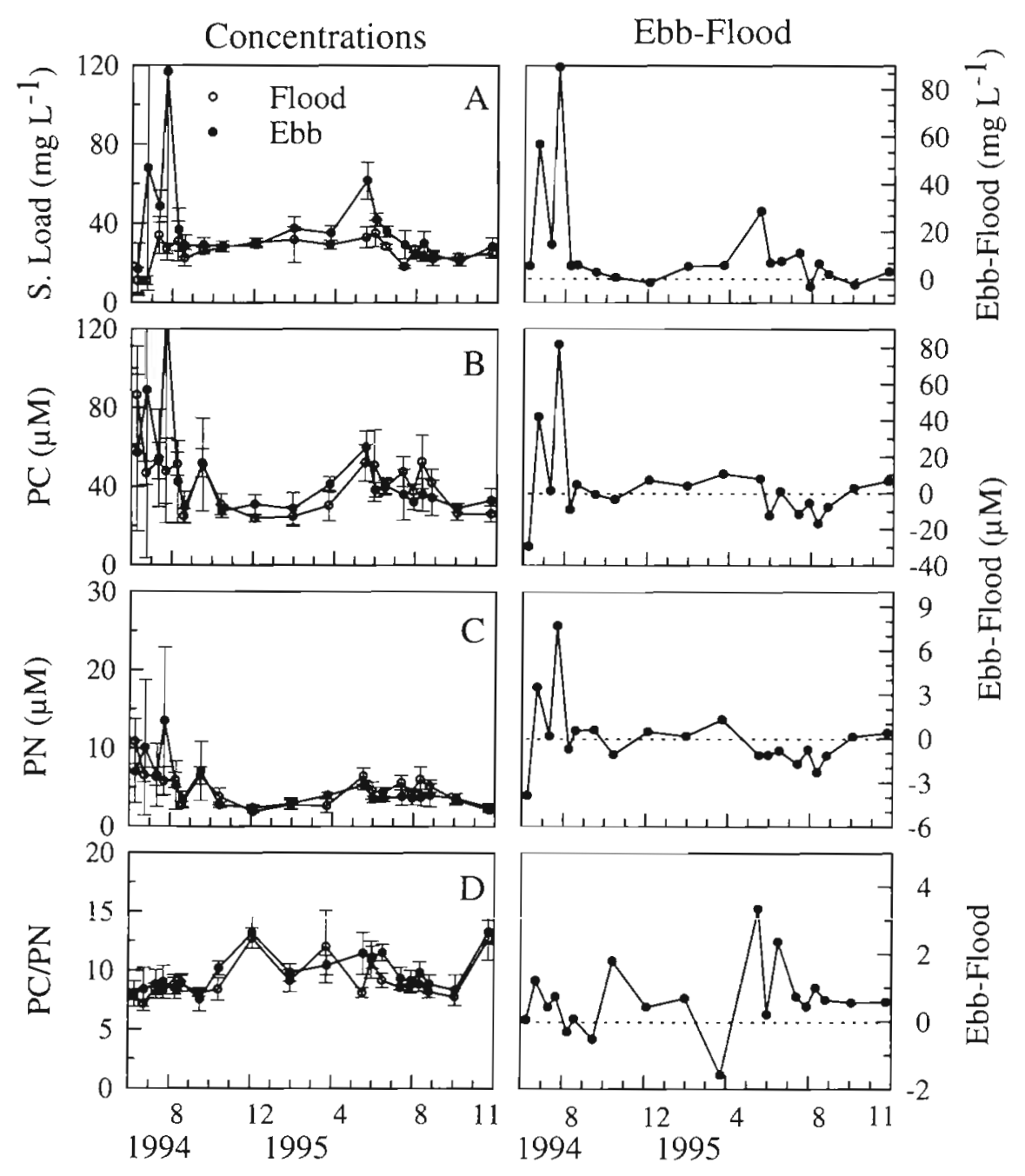

Fig. 7. Time series of concentrations (average of the 10 stations) (left panels) and fluxes (right panels) of: (A) suspended loads, (B) PC, (C) PN, and (D) PC/PN atomic ratios in the water column during tidal floods and ebbs for 1994 and 1995 . For concentrations, error bars $= \pm 1 \mathrm{SE}(\mathrm{n}=10)$. Flux is the difference between measurements made during ebb and flood tides (ebb minus flood); values above 0 (above the dashed line) indicate a flux out of the sediment, and those below 0 show a flux into the sediment

et al. 1995b,c, Amos et al. 1997). Because of the interacting dynamics, other variables did not appear to be correlated with salinity during most tidal cycles (Fig. 9). Even suspended load, which should be related with freshwater, was not correlated with salinity. In spite of no long-term spatial pattern for salinity, chl a was the highest at Stn W3 during flood tides and at Stn W6 during ebb tides (Fig. 8). The highest $\mathrm{NH}_{4}$ at Stn W10 in 1995 might be related to the lowest salinity water which was freshly discharged from the river (Fig. 8),

\section{Nutrient flux}

Whether estuarine sediment is a sink or source of nutrients for the water column (Nixon 1981) remains an important question for the estuarine ecosystem, particularly with increasing anthropogenic input of nutrients to estuarine environments. The seasonal pattern of nutrient flux is crucial in order to understand this question. One important finding in this study was that $\mathrm{NH}_{4}$ was released into the water column between a flood tide and its following ebb tide. This release of $\mathrm{NH}_{4}$ always occurred except on 2 occasions (Fig. 10). The potential sources of $\mathrm{NH}_{4}$ to Sturgeon Bank are freshwater from the river, flood water, direct excretion by benthic animals, interstitial water which contains nutrients from mineralization and infaunal activities, and excretion by zooplankton and other animals that come with the flood tide waters. It has been demonstrated on a mudflat in France that benthic feeding activity increased when flood tide water swept over the sediment and, as a result, $\mathrm{NH}_{4}$ was excreted and 


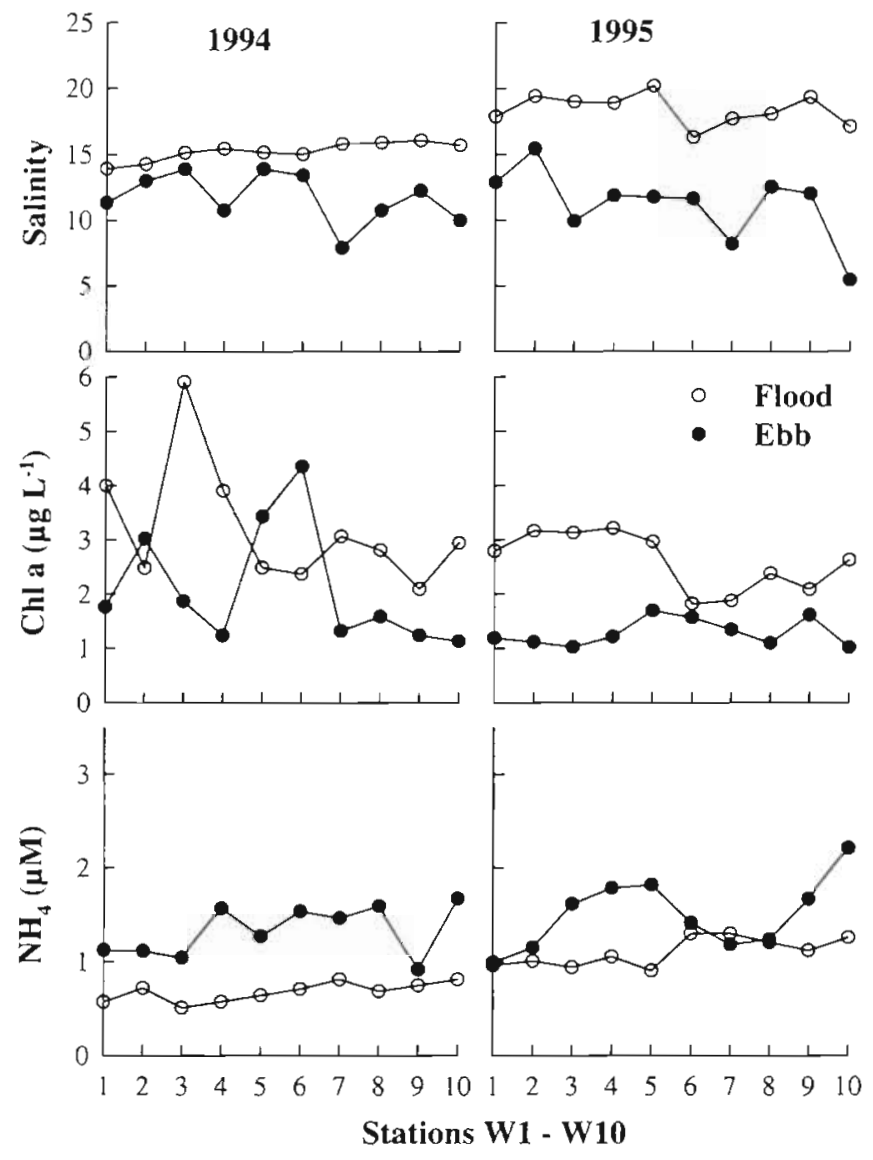

Fig. 8. Yearly average of salinity, chl $a$ and $\mathrm{NH}_{4}$ at each station in the water column during tidal floods and ebbs for 1994 and 1995

released into the water (Rybarczyk et al. 1993). The activities of benthic macrofauna were also observed to result in enhanced fluxes of nutrients out of the sediment (Watson et al. 1993).

In the current study, chl $a$ in flood tide waters was apparently lost from the water column in most months of 1994 and 1995 (Fig. 10). The possible mechanisms by which chl a can decrease in the water column are sedimentation, and feeding by benthic and pelagic animals. Sedimentation should result in a correlation between chl a and suspended loads, or between their fluxes, which was not the usual case for the former (Fig. 11) and not significant for the latter (Table 1). Therefore, animal feeding was likely responsible for this loss of chl a and, therefore, may have contributed to the observed $\mathrm{NH}_{4}$ flux. However, there was no significant correlation between fluxes of chl a and $\mathrm{NH}_{4}$. This lack of correlation suggests that other processes are also operating, such as the flux of $\mathrm{NH}_{4}$ out of the sediment due to much higher concentrations in the interstitial water. The release of $\mathrm{NH}_{4}$ into the overlying water probably occurs more rapidly when water is sweeping over the sediment surface. $\mathrm{NH}_{4}$ concentrations in the pore water on Sturgeon and Roberts Banks to the south of the Steveston Jetty were found to range from 200 to $1000 \mu \mathrm{M}$ in the top $1 \mathrm{~cm}$ of sediment (Yin et al. unpubl. data), much higher than in the water column. After the initial release of $\mathrm{NH}_{4}$ into the water column, the exchange between sediment and the water column is dependent on the gradient of $\mathrm{NH}_{4}$ at the water-sediment interface. The flux of $\mathrm{NO}_{3}$ not only supported the observation of the exchange in $\mathrm{NH}_{4}$, but also indicates the exchange of $\mathrm{NO}_{3}$ at the water-sediment interface at the same time. In fact, the nutrient concentrations that we measured during the late stage of the flood tide might have contained $\mathrm{NH}_{4}$ and $\mathrm{NO}_{3}$ from this exchange process as well as from the initial release; our values would thus be an underestimate of fluxes of $\mathrm{NH}_{4}$ and $\mathrm{NO}_{3}$ from the sediments on this bank.

\section{Nutrient sources}

The almost constant flux of $\mathrm{NH}_{4}$ into the water column raises the question of the source of nitrogen. The estimate of $\mathrm{NH}_{4}$ flux (out of the sediment) using the time-weighted averaging method (instead of an average over the number of sampling points aver time) was $1.25 \mathrm{mM} \mathrm{m}^{-2} \mathrm{~d}^{-1}$. However, based on the measured PN data, the PN flux averaged with the time-weighted method was estimated to be only $0.38 \mathrm{mM} \mathrm{m}^{-2} \mathrm{~d}^{-1}$ (into the sediment). This was not sufficient to support the $\mathrm{NH}_{4}$ flux. On the other hand, the daily chl a flux was

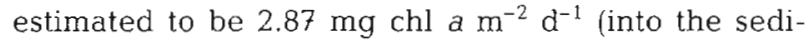
ment). This value represents $12.06 \mathrm{mM} \mathrm{m}^{-2} \mathrm{~d}^{-1}$ of PN using the regression equation obtained for the Strait of Georgia (Yin et al. 1996). The estimated flux of $\mathrm{NH}_{4}$ was only about $10 \%$ of this chl a-PN flux. One plausible explanation for this discrepancy between the 2 estimates is that PN contained a large portion of detritus of terrestrial origin. PN (including chl a) could settle onto the sediment and be resuspended during the period between a flood tide and the next ebb tide. Assuming benthic feeding selectively utilized chl $a$, the resuspended PN contained even more detritus of terrestrial origin. This is suggested by higher $\mathrm{C} / \mathrm{N}$ ratios during ebb tides than flood tides (Fig. 7). In addition, it is interesting to note that a significant correlation between chl a and PN occurred more frequently during flood tides than during ebb tides (12 vs 6 times) (Fig. 11). The notion of resuspension of detritus was supported by a highly significant correlation between fluxes of suspended load, PC and PN (Fig. 7, Table 1). It explains the small flux of PN compared to the large flux of chl a, although there was a weak correlation between the 2 fluxes (Table 1). 


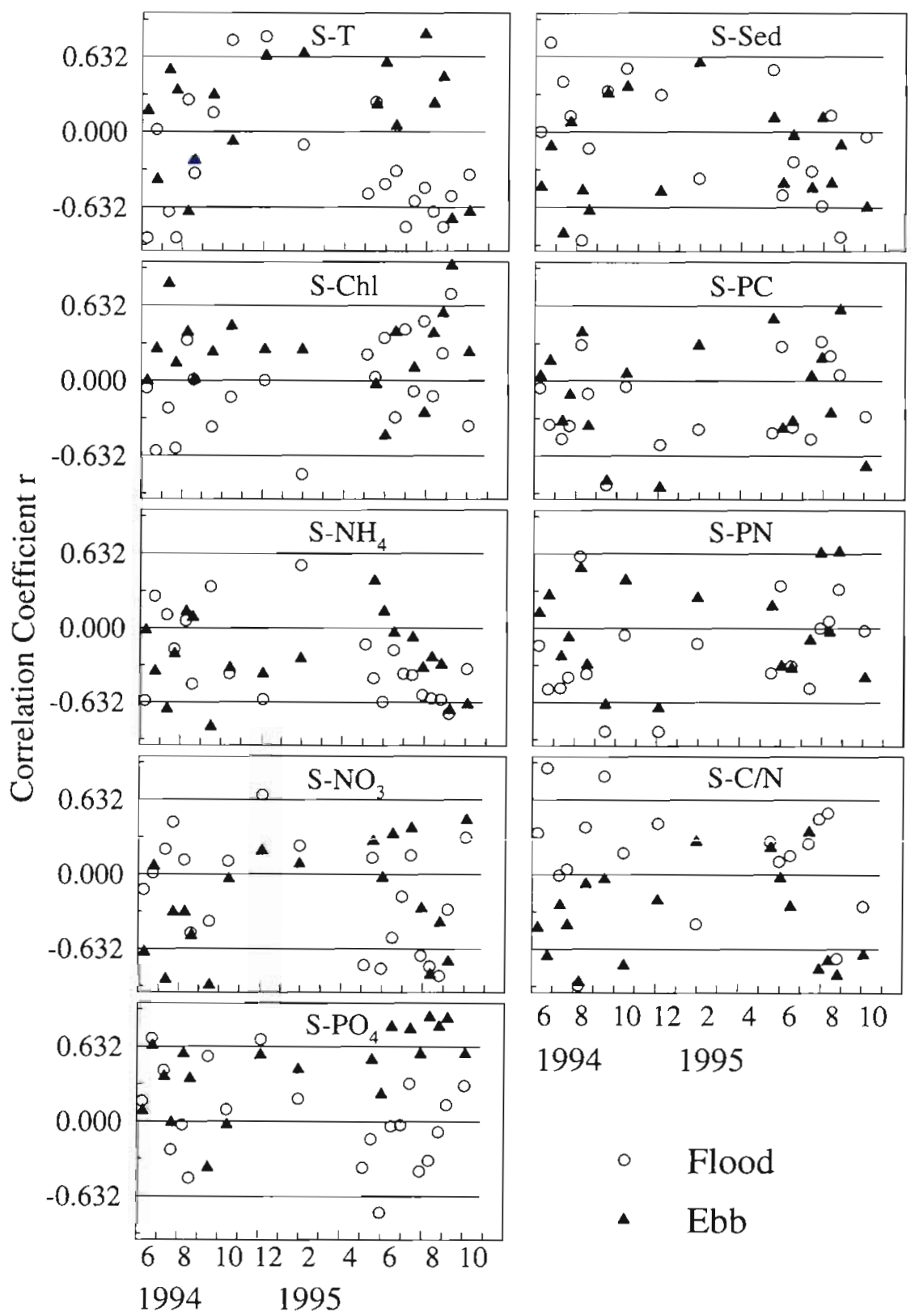

Fig. 9. Correlation between salinity (S) and other variables, including temperature (T), chl a, $\mathrm{NH}_{4}, \mathrm{NO}_{3}, \mathrm{PO}_{4}$, suspended load (Sed), PC, PN, and PC/PN (C/N) ratios during 1994 and 1995. Each point represents a correlation coefficient $r$ among 10 stations during a flood tide or an ebb tide. The 2 horizontal lines at -0.632 and 0.632 are critical values for $r$; points above 0.632 or below -0.632 are significant at $p<0.05$ (Zar 1984)

Effects of tidal cycles on the exchange of nutrients between the water column and sediment were evident for Sturgeon Bank. When flood tide water comes onto the flat, chl $a$ and other particulate organic matter are ingested by benthic animals. Some portion of the organics may be deposited onto the sediment, whereas another portion may be resuspended. Particulate organic matter not only comes from the Strait of Georgia, but also comes from the riverine plume originating from the Main Arm and Middle Arm of the Fraser River. When organics are deposited onto the sediment, they will be subjected to bacterial decomposition. Buried organics are decomposed and dissolved in the interstitial water. The exchange of dissolved constituents is subject to the gradient of a particular constituent at the sediment-water interface. Earlier studies showed that the intertidal flat was rich in organic matter before sewage effluent was diverted (Otte \& Lev- 


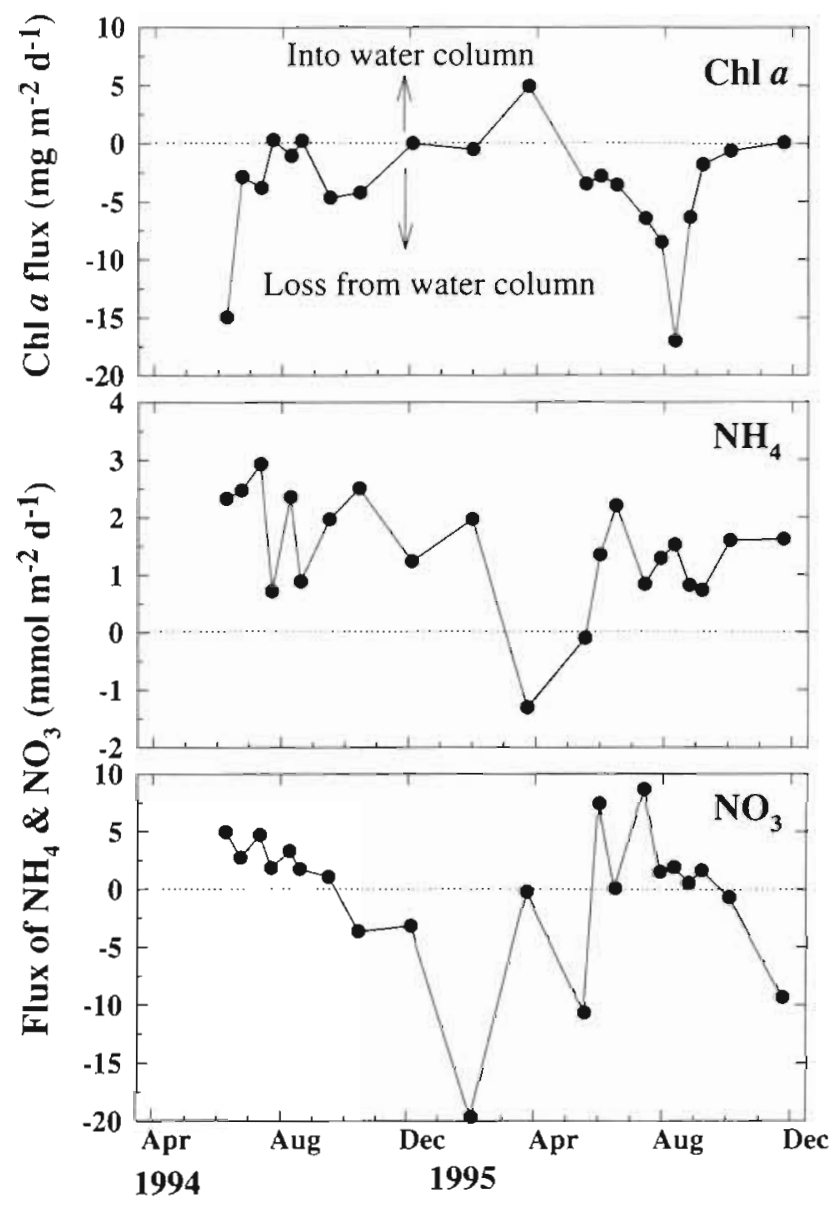

Fig. 10. Time series of fluxes of chl $a_{1} \mathrm{NH}_{4}$ and $\mathrm{NO}_{3}$ in the water column during tidal floods and ebbs for 1994 and 1995

ings 1975). Presumably, there must have been a large flux of $\mathrm{NH}_{4}$ out of the sediment right after the diversion of sewage effluent. A few years later, in 1994, our data on fluxes of nitrogen ( $\mathrm{PN}, \mathrm{NO}_{3}$ and $\mathrm{NH}_{4}$ ) did not show an internal source of nitrogen from this organic contamination. Sturgeon Bank cannot be considered a eutrophied flat when the flux of $\mathrm{NH}_{4}$ is compared with other systems (Table 2). The $\mathrm{NH}_{4}$ flux from the sediment to the water column on Sturgeon Bank was higher than one observed from deep water sediments (Blackburn et al. 1996), and within the range of the York River, Virginia (Rizzo 1990), a subtidal area of Mobile Bay, Alabama (Cowan et al. 1996), and the Chesapeake Bay (Boynton \& Kemp 1985). However the $\mathrm{NH}_{4}$ flux was smaller than the flux from eutrophied sediments of the Bay of Fundy, Canada (Anderson 1986), and a hypertrophic fish pond in Israel (Krom 1991). The results indicating a recovery from sewage pollution are also supported by concentrations of $\mathrm{NH}_{4}$ which are within the range observed for the Strait of Georgia (Clifford et al. 1992). Therefore, our results show that the water column on Sturgeon Bank is no longer markedly contaminated by organic pollution from the sediment over a scale of the entire flat. Unfortunately, comparisons with pre-diversion data cannot be made, because there are no historical data on the flux of $\mathrm{NH}_{4}$ from the sediments on Sturgeon Bank

Nutrient dynamics in the water column and sediments are an essential process in the ecosystem of Sturgeon and Roberts Banks and form a central link among different components of the ecosystem. The finding that Sturgeon Bank is a sink for PN and chl a indicates that phytoplankton productivity in the Strait of Georgia provides a constant food source for Sturgeon Bank, which is the largest intertidal flat for the largest number of waterfowl in western Canada. In turn, Sturgeon Bank provides remineralized nutrients to the overlying water column that fuel primary productivity in the water column. This source of nutrients is particularly important during late spring and summer when nutrient concentrations are low in the Strait of Georgia (Yin et al. 1997b).

Most previous estimates of nutrient flux have been based on chamber incubations. We believe that our approach of treating the entire intertidal flat as an in-

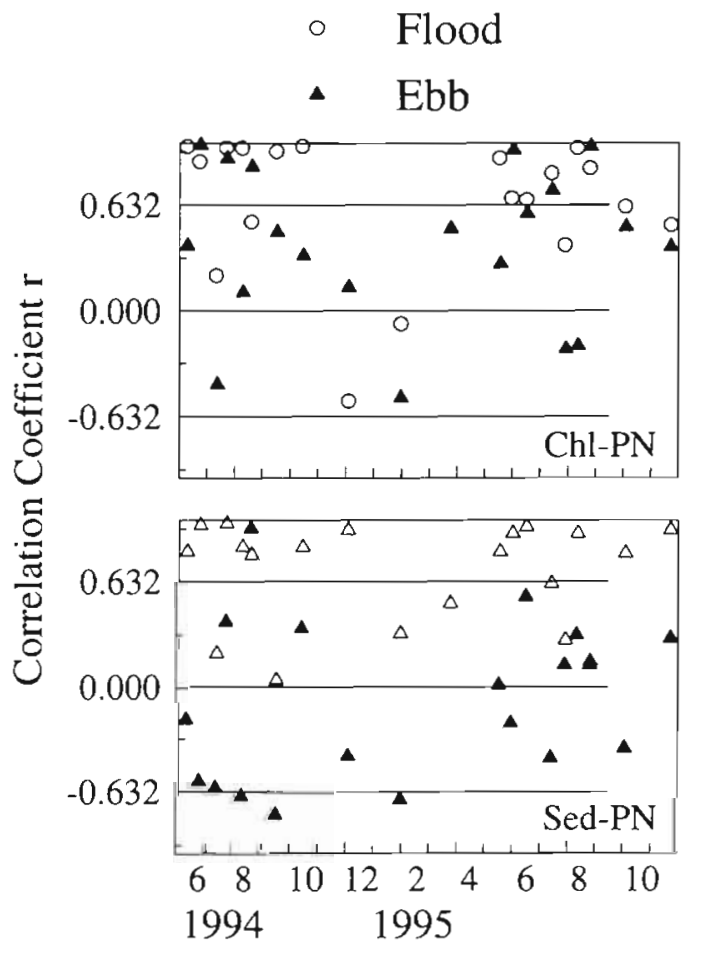

Fig. 11. Correlation between chl $a$ and PN and between suspended loads (Sed) and PN. Each point represents a correlation coefficient $r$ among 10 stations during a tidal flood or ebb. The 2 horizontal lines at -0.632 and 0.632 are critical values

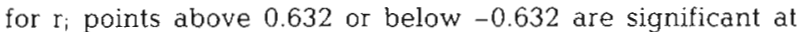
$\mathrm{p}<0.05$ (Zar 1984) 
Table 1. Correlation coefficient $r$ between fluxes of different parameters for 1994 and 1995, calculated using Microsoft Excel (Ver. 7). Pignificant correlation at $\mathrm{p}<0.05(\mathrm{n}=20)$. The statistical test for significance is based on critical values of $\mathrm{r}$ (Zar 1984) (Sal, salinity; Temp, temperature; Sed, suspended loads; PC, particulate carbon; PN, particulate nitrogen; C/N, PC/PN atomic ratios)

\begin{tabular}{|c|c|c|c|c|c|c|c|c|c|}
\hline & Temp & Chl a & $\mathrm{NH}_{4}$ & $\mathrm{NO}_{3}$ & $\mathrm{PO}_{4}$ & Sed & $\mathrm{PC}$ & PN & $C / N$ \\
\hline Sal & -0.101 & 0.066 & -0.002 & 0.032 & 0.292 & 0.029 & 0.042 & 0.088 & -0.427 \\
\hline Temp & & 0.161 & 0.291 & $-0.523^{\circ}$ & $-0.562^{*}$ & -0.258 & -0.126 & -0.118 & 0.052 \\
\hline ChI a & & & -0.336 & -0.301 & -0.153 & 0.167 & $0.510^{\circ}$ & $0.584^{\circ}$ & -0.204 \\
\hline $\mathrm{NH}_{4}$ & & & & 0.077 & 0.164 & -0.091 & -0.188 & -0.171 & 0.157 \\
\hline $\mathrm{NO}_{3}$ & & & & & $0.836^{\circ}$ & 0.090 & -0.121 & -0.061 & -0.322 \\
\hline $\mathrm{PO} 4$ & & & & & & 0.262 & 0.096 & 0.158 & -0.385 \\
\hline Sed & & & & & & & $0.875^{\circ}$ & $0.794^{\circ}$ & 0.231 \\
\hline $\mathrm{PC}$ & & & & & & & & $0.972^{*}$ & 0.107 \\
\hline PN & & & & & & & & & -0.097 \\
\hline
\end{tabular}

Table 2. Comparison of $\mathrm{NH}_{4}$ fluxes from the sediments in other studies. Values in mmol N m $\mathrm{h}^{-1}$ in the literature were converted to $\mathrm{mmol} \mathrm{N} \mathrm{m}^{-2} \mathrm{~d}^{-1}$ by multiplying by 24

\begin{tabular}{|llll|}
\hline Location & Duration & $\begin{array}{c}\mathrm{NH}_{4} \text { flux } \\
\text { (mmol N m} \mathrm{m}^{-1} \text { ) }\end{array}$ & Source \\
\hline Intertidal flat, Sturgeon Bank, Canada & Yearly & 1.25 (yearly average) & This study \\
Shallow, York River, Virginia & Mar-Dec & $-0.5-8.74$ & Rizzo (1990) \\
Lab. measurement, Kattegat sediment, Denmark & Oct & 1.6 (maximum) & Sündback \& Granéli (1988) \\
Intertidal beach, Nahant Bay, Massachusetts, USA & Yearly & $<2.4$ (typically) & Pregnall \& Miller (1988) \\
Hypertrophic fish porad, Israel & Jan-Mar & 16.1 & Krom (1901) \\
Arctic 170-2577 m deep, Svalbard, Norway & Jun-Jul 1991 & $-0.02-0.34$ & Blackburn et al. (1996) \\
Subtidal, Mobile Bay, Alabama, USA & Yearly & $-0.53-4.34$ & Cowan et al. (1996) \\
Chesapeake Bay, USA & Aug-May & $1-13.5$ & Boynton \& Kemp (1985) \\
Intertidal mudflat, Bay of Fundy, Nova Scotia, Canada & Aug-Dec & Control: 4.32 & Andersen (1986) \\
& & Detritus-enriched: 7.2 & \\
\hline
\end{tabular}

cubation chamber is unique and innovative. Changes in physical, chemical and biological variables between flood and ebb tides represent real signals of processes over a spatial scale of the entire flat. This approach gave reasonable estimates of nutrient fluxes compared with other studies and offers a new way of studying the nutrient flux in an intertidal area. This approach is particularly important in studying environmental contamination of intertidal flats because observations are based on the entire flat and bear implications on an ecosystem level.

Acknowledgements. Leo Lebele, Steven Short, Allen Milligan, Joe Arvai and Mingxin Guo provided assistance during field sampling. We thank the Canadian Coast Guard for providing the Hovercraft time that was used to obtain our samples and the officers and crew of Richmond Hovercraft Base for their assistance. Discussions with Drs Colin Levings, Colin Gray, Bob Elner, Leah Bendell-Young, Mary Sewell and Mr Eric McGreer, as well as other colleagues involved in the Fraser River Estuary Management Plan (FREMP) workshops, were very helpful. We are indebted to Dr Colin Gray for funding through Environment Canada as part of the Fraser River Action Pları.

\section{LITERATURE CITED}

Amos CL, Feeney TD, Sutherland TF, Luternauer JL (1997) The stability of fine-grained sediments from the Fraser River delta. Estuar Coast Shelf Sci 45:507-524

Anderson $F \varnothing$ (1986) Influence of Spartina detritus enrichment on exchange of nutrients between sediment and water in an intertidal area of Bay of Fundy. Mar Ecol Prog Ser 29: $7-14$

Arvai JL (1997) The population dynamics and production of Corophium salmonis (S) and Macoma balthica (L) on an estuarine mudflat in response to effluent diversion from a sewage plant, Sturgeon Bank, British Columbia. MSc thesis, University of British Columbia, Vancouver

Blackburn TH, Hall PO, Hulth S, Landén A (1996) Organic-N loss by efflux and burial associated with a low efflux of inorganic $\mathrm{N}$ and with nitrate assimilation in Arctic sediments (Svalbard, Norway). Mar Ecol Prog Ser 141:283-293

Boynton WR, Kemp WM (1985) Nutrient regeneration and oxygen consumption by sediments along an estuarine salinity gradient. Mar Ecol Prog Ser 23:45-55

Clifford PJ, Yin K, Harrison PJ, St. John MA, Goldbiatt RH, Varela DF (1992) Plankton production and nutrient dynamics in the Fraser River plume, 1991. Manuscript Report No. 59: Department of Oceanography, University of British Columbia, Vancouver, BC

Collos Y, Yin K, Harrison PJ (1992) A note of caution on reduction conditions when using the cadmium-copper column 
for nitrate determinations in aquatic environments of varying salinities. Mar Chem 38:325-329

Cowan ILW, Pennock JR, Boynton WR (1996) Seasonal and interannual patterns of sediment-water nutrient and oxygen fluxes in Mobile Bay, Alabama (USA): regulating factors and ecological significance. Mar Ecol Prog Ser 141:229-245

Demuth S, Casilla E, Wolfe DA, McCain BB (1993) Toxicity of saline and organic solvent extracts of sediments from Boston Harbor, Massachusetts and the Hudson River-Raritan Bay Estuary, New York using the Microtox bioassay Arch Environ Contam Toxicol 25:377-386

Feeney TD (1995) Physical controls on the distribution of contaminants on Sturgeon Bank, Fraser River delta, British Columbia. MSc thesis, University of British Columbia Vancouver

Fisher TR, Carlson PR, Barber RT (1982) Sediment nutrient regeneration in three North Carolina estuaries. Estuar Coast Shelf Sci 14:101-116

Geyer WR, Farmer DM (1989) Tide-induced variation of the dynamics of a salt wedge estuary. J Phys Oceanogr 19: $1060-1072$

Hager SW, Gordon LI, Park PK (1968) A practical manual for the use of the Technicon Autoanalyzer in seawater nutrient analysis. Dept of Oceanogr, Oregon State University, Corvallis, OR, OSU Ref 68-73

Kemp WM, Boynton WR (1984) Spatial and temporal coupling of nutrient inputs to estuarine primary production: the role of particulate transport and decomposition. Bull Mar Sci 35:522-535

Krom MD (1991) Importance of benthic productivity in controlling the flux of dissolved inorganic nitrogen through the sediment-water interface in a hypertrophic marine ecosystem. Mar Ecol Prog Ser 78:163-172

LeBlond PH (1983) The Strait of Georgia: functional anatomy of a coastal sea. Can J Fish Aquat Sci 40:1033-1063

Luternauer JL, Murray JW (1973) Sedimentation on the western delta-front of the Fraser River, British Columbia. Can $J$ Earth Sci 10:1642-1663

McGreer ER (1979) Sublethal effects of heavy-metal contaminated sediment on the bivalve Macoma balthica (L). Mar Pollut Bull 10:259-262

Means JC, Hassett JJ, Wood SG, Banwart WL (1989) Sorption properties of energy-related pollutants and sediments. In: Jones PW, Leber P (eds) Polynuclear aromatic hydrocarbons. Ann Arbor Science Publishers, Ann Arbor, MI, p $327-340$

Nixon SW (1981) Remineralization and nutrient cycle in coastal marine ecosystems. In: Neilson BJ, Cronin LE (eds) Estuaries and nutrients. Humana Press, Clifton, NJ, p $111-137$

Nixon SW, Pilson MEQ (1983) Nitrogen in estuarine and coastal marine ecosystems. In: Carpenter EJ, Capone DG (eds) Nitrogen in the marine environment. Academic Press, New York, p 565-648

Otte G, Levings CD (1975) Distribution of macroinvertebrate communities on a mudflat influenced by sewage. Fraser River Estuary. B C Fish Mar Ser Tech Rep 476:1-78

Parsons TR, Stephens K, LeBrasseur RJ (1969) Production studies in the Strait of Georgia. Part I. Primary production under the Fraser River plume, February to May, 1967 $J$ Exp Mar Biol Ecol 3:27-38

Parsons TR, Maita Y, Lalli CM (1984) A manual of chemical and biological methods for seawater analysis. Pergamon Press, Oxford

Pregnall AM, Miller SL (1988) Flux of ammonium from surfzone and nearshore sediments in Nahant Bay, Massachu-

Editorial responsibility: Otto Kinne (Editor),

Oldendorf/Luhe, Germany setts, USA in relation to free-living Pilayella littoralis. Mar Ecol Prog Ser 50:161-167

Rizzo WM (1990) Nutrient exchange between the water column and a subtidal benthic microalgal community. Estuaries 13:219-226

Ross L (1998) Intertidal benthic primary productivity following sewage effluent diversion on Sturgeon Bank, Fraser River delta. MSc thesis, University of British Columbia, Vancouver

Rybarczyk H, Desprez M, Ducrotoy JP, Olivesi R, Delesmont R, Jamet F, Elkaim B (1993) Dynamics of nutrients and faecal bacteria in a macrotidal estuary, the Bay of Somme (France). Neth J Aquat Ecol 27:395-404

Sewell MA (1996) Detection of the impact of predation by migratory shorebirds: an experimental test in the Fraser River estuary, British Columbia (Canada), Mar Ecol Prog Ser 144:23-40

Sharp JH (1974) Improved analysis for 'particulate organic carbon and nitrogen' from seawater. Limnol Oceanogr 19: 984-989

Slawyk G, Macisaac JJ (1972) Comparison of two automated ammonium methods in a region of coastal upwelling. Deep-Sea Res 19:521-524

Sundbäck K, Granéli W (1988) Influence of microphytobenthos on the nutrient flux between sediment and water: a laboratory study. Mar Ecol Prog Ser 43:63-69

Thomas CA, Bendell-Young LI (1998) Linking the sediment geochemistry of an intertidal region to metal bioavailability in the deposit feeder Macoma balthica. Mar Ecol Prog Ser 173:197-213

Watson PG, Frickers PE, Howland RJM (1993) Benthic fluxes of nutrients and some trace metals in the Tamar estuary, SW England. Neth J Aquat Ecol 27:135-146

Wolave TG, Zieman J (1983) Effects of water column, sediment and time over the tidal cycle on the chemical composition of tidal water in a mesohaline marsh. Mar Ecol Prog Ser 12:123-130

Wood ED, Armstrong FAJ, Richards FA (1967) Determination of nitrate in seawater by cadmium-copper reduction to nitrite. J Mar Biol Assoc UK 47:23-31

Yin K, Harrison PJ, Pond S, Beamish RJ (1995a) Entrainment of nitrate in the Fraser River plume and its biological implications. I. Effects of salt wedge. Estuar Coast Shelf Sci 40:505-528

Yin K, Harrison PJ, Pond S, Beamish RJ (1995b) Entrainment of nitrate in the Fraser River plume and its biological implications. II. Effects of spring vs neap tides and river discharge. Estuar Coast Shelf Sci 40:529-544

Yin K, Harrison PJ, Pond S, Beamish RJ (1995c) Entrainment of. nitrate in the Fraser River plume and its biological implications. III. Effects of winds. Estuar Coast Shelf Sci 40:545-558

Yin K, Harrison PJ, Goldblatt RH, Beamish RJ (1996) Spring bloom in the central Strait of Georgia: interactions of river discharge, winds and grazing. Mar Ecol Prog Ser 138: $255-263$

Yin K, Harrison PJ, Goldblatt RH, Beamish RJ (1997a) Factors controlling the timing of the spring bloom in the Strait of Georgia estuary. Can J Fish Aquat Sci 54:1985-1995

Yin K, Goldblatt RH, Harrison PJ, Clifford PJ, St John MA, Beamish RJ (1997b) Importance of wind and river discharge in influencing nutrient dynamics and phytoplankton production in summer in the Central Strait of Georgia Mar Ecol Prog Ser 161:173-183

Zar JH (1984) Biostatistical analysis, 2nd edn, Prentice Hall Englewood Cliffs, $\mathrm{N} J$

Submitted: June 28, 1999; Accepted: October 26, 1999

Proofs received from author(s): March 17, 2000 